\title{
Población y gobierno en el Buenos Aires colonial. Una aproximación al estudio sobre las tensiones generadas por el crecimiento demográfico en la ciudad (1740-1776)
}

\author{
Bettina Laura SIDY \\ CONICET-IDEAS-FFyL, UBA \\ bettinasidy@gmail.com
}

Recepción: 29 de agosto de 2014 / Revisión: 15 de enero de 2015

Aceptación: 26 de enero de 2015 / Publicación: Diciembre 2015

\begin{abstract}
RESUMEN
Analizaremos aquí la relación entre población y gobierno, en la ciudad de Buenos Aires, a partir de las tensiones generadas por el arribo de nuevos individuos, una elite local a cargo de los asuntos comunales con fuertes intereses en el comercio y unos funcionarios españoles que progresivamente se fueron haciendo del ideario propuesto por la dinastía borbónica, no obstante verse también implicados en las lógicas locales. Nos interesa observar cuál era la visión de los gobernadores respecto al desenvolvimiento cotidiano de la ciudad, cuáles sus preocupaciones e intereses y de qué modos fueron variando los dispositivos a los que apelaron para organizar la vida cotidiana en el período que va desde 1740 hasta 1776.
\end{abstract}

Palabras clave: Gobierno, Políticas, Buenos Aires, Argentina, Siglo XVIII.

\section{Population and Government in Colonial Buenos Aires. An Approach to the Study of the Tensions Generated by Demographic Growth in the City (1740-1776)}

\begin{abstract}
The relationship between population and government in the City of Buenos Aires is analyzed, focusing on the tensions generated by the arrival of new individuals, a local elite with great interests in commerce and in charge of community affairs, and Spanish functionaries that progressively adopted the ideals of the Bourbon Dynasty, despite also being implicated in local logics. It interests us to observe the governors' perspectives with respect to everyday developments in the city, their preoccupations and interests, and how they would vary the mechanisms to which they resorted in order to organize daily life, in the period defined between 1740 and 1776.
\end{abstract}

Keywords: Government, Politics, Buenos Aires, Argentina, $18^{\text {th }}$ Century.

Sumario: 1. La población en el espacio. 2. Primeras reglamentaciones (1740-1760). 3. La conceptualización del "bien común". Los transeúntes y la categoría del "vago" (1740-1760). 4. Extranjeros, entre la ambigüedad y el oportunismo (1740-1760). 5. El auge del comercio interno y los conflictos derivados (1760-1776). 6. A modo de cierre: De la reiteración a la centralización (1770-1776). 7. Referencias bibliográficas. 


\section{LA POBLACIÓN EN EL ESPACIO}

Durante el siglo XVII y buena parte del XVIII, la ciudad de Buenos Aires se caracterizó por ser un espacio urbano marginal orientado al comercio legal y extra legal. No obstante desde la segunda mitad del siglo XVIII, la corona española fue paulatinamente realzando el status político y administrativo de la ciudad-puerto ${ }^{1}$. En consecuencia, una multitud de peninsulares -funcionarios y comerciantes- y de migrantes internos, se fueron asentando en Buenos Aires ${ }^{2}$, al mismo tiempo crecía la llegada de esclavos $^{3}$ y el tránsito de arrieros, estibadores, carreteros y mercaderes ocasionales que pasaban por la ciudad ${ }^{4}$. El ritmo del crecimiento demográfico en Buenos Aires provocó una gran concentración de población en los espacios centrales que fueron apropiados y utilizados por estos actores con distintos fines, ya fueran habitacionales, comerciales, de transito y/o recreativos.

Este panorama fue suscitando situaciones novedosas y en cierta medida conflictivas para el desenvolvimiento cotidiano de Buenos Aires. En este sentido, desde la década de 1740 los Gobernadores comenzaron a publicar, con una periodicidad inédita, ordenanzas de gobierno tendientes a la regulación y al ordenamiento tanto de los espacios urbanos -calles, veredas, pulperías, tiendas, plazas, edificaciones-, como de las actividades de los porteños en los mismos ${ }^{5}$. Se implementaron diversos dispositivos de tipo político-jurídico como los bandos y los autos de los gobernadores ${ }^{6}$, la realización de padrones y registros de población cada vez más minuciosos y la designación de funcionarios especiales como los alcaldes de barrio, todo ello mediado también por disputas en torno a las prerrogativas políticas de los sujetos y las instituciones en juego. Al mismo tiempo el desarrollo comercial de Buenos Aires implicó nuevos niveles de competencia que se expresaron en el devenir cotidiano de la ciudad y en los que los actores intervinientes se hicieron de ciertos discursos gubernamentales a la hora de defender sus intereses mercantiles.

Analizaremos aquí, la relación entre población y gobierno a partir de las tensiones generadas por el arribo de nuevos individuos, una elite local a cargo de los asuntos

1 El renovado interés en el área se debió en parte a los intereses económicos y políticos que la ciudad suscitó entre las potencias europeas quienes buscaban dominar la salida atlántica de la plata potosina y la pretensión de la Corona española por defender y fortalecer a la ciudad-puerto.

2 DíAz, 1998.

3 Johnson, 2011 y STUder, 1958.

4 SANTAMaría, 2006.

5 Tópicos referidos al gobierno comunal, tales cómo, el tránsito, la "peligrosidad" en las calles, el abasto urbano, el modo en que fue creciendo el comercio en la ciudad y el desenvolvimiento de los mecanismos judiciales fueron recurrentemente regulados. También se publicaron mandatos tendientes al ordenamiento de la ciudad en relación al aumento de la basura, el desarrollo de las construcciones de la ciudad y el esquema urbano de desagües. "Bandos de los Gobernadores del Río de la Plata", Buenos Aires, 1741-1752, Archivo General de la Nación Argentina (AGN) Sala IX, Gobierno, 9-8-10-1; "Bandos de los Gobernadores del Río de la Plata", Buenos Aires, 1753-1762, AGN, Sala IX, Gobierno, 9-8-10-2; "Bandos de los Gobernadores del Río de la Plata", Buenos Aires, 1763-1777, AGN, Sala IX, Gobierno, 9-8-10-3.

6 Los bandos de gobierno se aplicaban a todos los grupos sociales y el conocimiento de sus normas llegaba a los distintos estratos de la sociedad. Se trata de textos de extensión reducida, las disposiciones están formuladas de manera sencilla y recurrente y las temáticas son relativas a situaciones cotidianas de la comunidad urbana. Los mandatos incluidos en los documentos no se derogaban unos a otros, sino que más bien tenían un carácter acumulativo. TAU AnZOÁTEGUi, 2004, p. 16. 
comunales con fuertes intereses en el comercio y unos funcionarios españoles que progresivamente se fueron haciendo del ideario propuesto por la dinastía borbónica, no obstante verse también implicados en las lógicas locales 7 . Nos interesa observar cuál era la visión de los gobernadores respecto al desenvolvimiento cotidiano de la ciudad, cuáles sus preocupaciones e intereses y de qué modos fueron variando los dispositivos a los que apelaron para organizar la vida cotidiana en el período comprendido entre 1740 y 1776. Delineamos para ello dos etapas, la primera iniciada en 1740 año en que los Gobernadores porteños retomaron la costumbre de publicar bandos tendientes a la organización de la población en el espacio. Consideramos que este cúmulo de ordenanzas sentó las bases para la formación de un particular discurso de control social, al atender de forma reiterada a determinadas problemáticas, pretendiendo con ello orientar la conducta de una cada vez más heterogénea población ${ }^{8}$. La etapa siguiente se inicia en la década de 1760 cuando, por un lado se agudizó la competencia en torno a las oportunidades comerciales que la ciudad proveía y por el otro se empezó a sentir en Buenos Aires la impronta borbónica respecto al gobierno urbano $^{9}$. Al mismo tiempo que el paulatino crecimiento económico y político de la ciudad impulsó nuevos conflictos que involucraron a distintos sectores de la población, las autoridades buscaron centralizar las ordenanzas y las instituciones destinadas a su organización. Tanto Cevallos (1756-1766) como Bucareli (1766-1770) implementaron medidas tendientes a un mayor conocimiento y control de la población -los padrones de extranjeros de parte del primero ${ }^{10}$, un verdadero censo de población "sin excepción de sexos ni edades" ordenado por Bucareli en 1766, que se completó

7 En Buenos Aires, la mayoría de los comerciantes estaban vinculados entre sí por relaciones de parentesco, conformando verdaderos clanes que reforzaban el papel de la ciudad como centro de influencia político, social y económico, ocupaban lugares prominentes en el gobierno comunal y mantenían estrechas relaciones con los funcionarios metropolitanos. Moutoukias da cuenta, ya en el siglo XVII, de la emergencia de una relación estable entre los grupos dominantes y las estructuras formales de autoridad como resultado de un complejo proceso cuyos orígenes estaban tanto en las acciones de los funcionarios como en las estrategias de los personajes más poderosos de las comunidades locales. Los miembros de la elite local buscaban el servicio al rey y el ejercicio de oficios que daba honor y crédito personal como parte de una lógica social que alimentaba la coexistencia de los objetivos generales de las instituciones con los intereses locales. Estos procesos configuraron unidades corporativas atravesadas por una multitud de relaciones sociales en cuyo interior se organizaban los intercambios de favores y recompensas como las interacciones que articulaban grupos de acción concretos. Ver Lugar, 1992; Gelman, 1989; Moutoukias, 2000; Socolow 1991.

8 Respecto a la conformación de un cierto discurso se control social retomamos las ideas esbozadas por BARRENECHE, 2001.

9 Retomamos así la cronología propuesta por Lorandi para pensar el reformismo borbónico. La autora marca dos etapas para el desarrollo de las reformas, 1763-1775, guiadas por el Conde de Aranda y Julián de Arriaga y 1776-1787 de la mano de don José De Gálvez, Marqués De Sonora. LorAndi, 2008, p. 15.

10 A partir de 1763 se estableció una matrícula de extranjeros en la que debía constar: edad, estado, oficio o ejercicio que tienen, la calle y casa en que viven (...) ninguno pueda mudarse de casa, después de hecha esta matrícula sin que proceda darme parte [al Gobernador] y que le conceda licencia por escrito sin cuyo requisito ninguno, ninguno los admitirá a vivir en sus casas. Bandos..., AGN, Sala IX, Gobierno, 8-10-2, f. 355). Mandato que se repitió en 1765 cuando Cevallos ordenó que se forme "asiento" de todos los ingleses y portugueses: "con especificación de los que sean casados o solteros, del oficio o modo de mantenerse que tuvieren y de las casas en que viven dentro o fuera de la ciudad". Bandos..., AGN, Sala IX, Gobierno, 8-10-3, f. 62). 
con la división de la ciudad en cuarteles ${ }^{11}$. Sin embargo fue Vertiz (1770-1776), quien realmente se ocupó de plantear una sistematización para el control y el registro de la población en el espacio de la ciudad.

A lo largo de estas dos etapas veremos cómo la vida urbana y la organización de su población se debatieron entre una lógica impuesta por el desarrollo de una heterogénea masa demográfica y una serie de políticas que buscaban imponer la presencia de un gobierno jurisdiccional. Al interior de dichas políticas pugnaron también los poderes de los actores intervinientes, todo lo cual estuvo mediado por la competencia en torno a las posibilidades comerciales que brindaba la creciente ciudad.

\section{PRIMERAS REGLAMENTACIONES (1740-1760)}

A partir de 1740 empezó a ser notable el esfuerzo de parte de los encargados del gobierno por limitar determinadas prácticas que se consideraron perjudiciales al funcionamiento de la ciudad, al mismo tiempo que se creyó necesario conocer a la creciente población. En 1744, a pedido del Gobernador Ortiz de Rozas (1742-1745), se llevó a cabo un padrón de la ciudad y de la campaña ${ }^{12}$ que constituyó el primer registro que excedió los fines militares ${ }^{13}$. A este mecanismo se añadió la publicación cada vez más periódica de bandos de gobierno, como recordatorio constante de aquellas conductas que eran aceptables y aquellas que no. En ellos se reiteraron y complejizaron las prohibiciones en torno a la portación, el uso, la fabricación y la venta de $\operatorname{armas}^{14} \mathrm{y}$ se sancionaron los desordenes generados por las corridas a caballo por las calles:

En cuanto al mal abuso que hay en esta ciudad en los que andan de noche a caballo corriendo por las calles resultan gravísimos inconvenientes (...) ordeno y mando que

11 Lamentablemente dicho censo no ha sido encontrado, según Ravignani se reconoce su existencia dado que aparece citado en un inventario de 1797. RAVIGNANI, 1920, p. 8.

12 AGN, 1930, p. 555-557.

13 En 1726 y 1738 se habían llevado a cabo dos empadronamientos de población con el objetivo limitado de contabilizar a los hombres disponibles para el servicio de armas. FACULTAD de Filosofía y LeTRAs, 1919 y Ravignani, 1920. Ravignani habla de 10.056 habitantes según el padrón de 1744, mientras que Socolow corrige esta cifra, que asciende a 11.600. Dado que el censo de 1744 no incluyó a sacerdotes, militares, consejeros ni a sus familias, Socolow extrae el tamaño de estas poblaciones de los datos de 1.738. JOHNSON Socolow, 1980, p. 330.

14 Se especificó la tenencia de armas blancas o en su defecto la orden de cortarles las puntas. Bandos..., AGN, Sala IX, Gobierno, 8-10-1, fs. 5-6, 69-70 y 79-80). La sanción se amplió luego prohibiendo a: "todo español, negro, indio ni mulato andar con bolas, ni las traigan debajo del lomillo". Bandos..., AGN, Sala IX, Gobierno, 8-10-1, f. 118). Andonaegui reiteró la prohibición en dos oportunidades más, en 1753 y en 1755. Bandos..., AGN, Sala IX, Gobierno, 8-10-2, fs. 18-19 y 118-119). Al asumir Cevallos (1756) extendió la proscripción a la fabricación y la venta de armas: "Ningún mercader ni otra persona alguna de esta ciudad pueda vender ni en las calle ni almacenes pistolas, trabucos ni armas blancas de las prohibidas ni los armeros las pueden fabricar componer ni vender sin licencia de este gobierno". Bandos..., AGN, Sala IX, Gobierno, 8-10-2, f. 150). Lo que fue reiterado por su sucesor Francisco Bucareli y Ursúa. Bandos..., AGN, Sala IX, Gobierno, 8-10-3, f. folios 87-89). Vertiz también detalló la prohibición en su primer bando de buen gobierno. TAu AnZoÁtegui, 2004, pp. 272-277. 
ninguna persona de cualquier estado, calidad y condición que sea desde la oración adelante ande corriendo a caballo por las calles de esta ciudad ni extramuros de ella ${ }^{15}$.

Con los años, se prohibió el uso del caballo por la noche, fuera al galope o simplemente al paso ${ }^{16}$, aunque lo mismo no tuviera mayor efecto ${ }^{17}$. Las actividades nocturnas en general representaron una preocupación en los bandos de los Gobernadores quienes fueron recurrentes en señalar el horario en que debían cerrarse las tiendas y las pulperías, "en verano hasta las diez y en invierno hasta las nueve", orden reiterada a los largo de los años intentando evitar el que por tener "abiertas a deshoras de la noche las dichas pulperías, tendejones y tiendas se originan juegos, borrachera y quimeras todo en perjuicio del bien público" 18 .

A partir de 1745 se incluyó, respecto a tiendas y pulperías, la veda de cualquier tipo de juegos bajo la pena de destierro a perpetuidad, luego aminorada a una multa variable de entre 25 y 500 pesos. Un año después, Andonaegui (1745-1755) denunciaba que con motivo de los juegos de naipes se originaban "varias pendencia, pleitos y puñaladas" ${ }^{19}$, vinculando así la prohibición respecto al ocio con la seguridad y asumiendo el incumplimiento respecto a la portación de armas vedadas, mandato que se reiteró en varias oportunidades, penalizando también a quienes consentían el desarrollo de dicho juegos ${ }^{20}$. La noción del juego como elemento pernicioso que habilitaría el desarrollo de borracheras y riñas se encontraba íntimamente vinculada a la valoración social del par trabajo-vagancia, cuestión ampliamente reflejada y

15 Bandos..., AGN, Sala IX, Gobierno, 8-10-1, f. 12.

16 Ibídem, fs. 79-80.

17 En 1746 Andonaegui denunciaba que: “.... sin embargo de lo referido se experimenta que a todas horas andan corriendo y al galope atropellando a cuantos topan por delante". Bandos..., AGN, Sala IX, Gobierno, 8-10-1, fs. 107-108 y 244). Denunciaba que los habitantes de la ciudad "han controvertido y abusado de este mandato originándose de esto varias averías que han sucedido" (Ibídem, f. 331), cuestión que reiteró Cevallos en 1756. Bandos..., AGN, Sala IX, Gobierno, 8-10-2, fs. 150-152). En 1759, Alonso de la Vega explicaba que "con motivo del grave desorden de andar corriendo a caballo a carrera y galopar por las calles de esta ciudad se experimentan muchos daños y perjuicios atropellando a cuantas personas encuentran y cometiendo otros excesos" (Ibídem, fs. 202-203). En 1769 el Cabildo solicitó al Gobernador Bucareli la publicación de un nuevo bando dados los "desórdenes que se experimentan con motivo de andar a carrera a caballo de día atropellando a los que encuentran y de noche cometiendo otros varios excesos". Bandos..., AGN, Sala IX, Gobierno, 8-10-3, f. 164. También ver: Bandos..., AGN, Sala IX, Gobierno, 8-10-2, f. 256 y Bandos..., AGN, Sala IX, Gobierno, 8-10-3, f. 87-89.

18 Bandos..., AGN, Sala IX, Gobierno, 8-10-2, f. 350. Asimismo se ordenaba el encendido de faroles en sus puertas luego del cierre con el fin de que se mantuviesen: "las calles claras y se eviten muchas ofensas que se cometen". Bandos..., AGN, Sala IX, Gobierno, 8-10-1, f. 35. Unos años después se ordenaba el encendido nocturno de faroles en los "cuartos que tienen puerta a la calle en que se está trabajando en los oficios". Bandos..., AGN, Sala IX, Gobierno, 8-10-2, f. 350. Lo que fue reiterado: Bandos..., AGN, Sala IX, Gobierno, 8-10-1, fs. 79-80; Bandos..., AGN, Sala IX, Gobierno, 8-10-2, fs. 150-152; Bandos..., AGN, Sala IX, Gobierno, 8-10-3, fs. 87-89.

19 Bandos..., AGN, Sala IX, Gobierno, 8-10-1, fs. 80 y 91.

20 Ibídem, fs. 172-173; Bandos..., AGN, Sala IX, Gobierno, 8-10-2, fs. 120-121, 150-152, 194-195. Las sucesivas prohibiciones fueron reflejando las prácticas en torno a esta forma de ocio y sus transformaciones. En 1759, De la Vega -además de elevar las multas a 500 pesos- atendía al hecho de que los jugadores optaban por "ponerse en alguna parte secreta de la misma casa citada o en otros parajes a continuar con estos juegos". Bandos..., AGN, Sala IX, Gobierno, 8-10-2, f. 195. 
sancionada en los bandos de gobierno. Al respecto, en 1761, Larrazabal -gobernador interino- explicaba que:

En los juegos de bola de aro que hay en diferentes canchas de esta ciudad y de bolos se experimenta el perjuicio y desorden de que en los días de trabajo se juntan a jugar los sujetos que deben acudir al trabajo diario faltando a él y a la atención de su familia de tal forma que enviciados en el juego suelen jugar hasta la ropa de su uso y la de sus mujeres ${ }^{21}$.

Se prohibía a los dueños de las canchas habilitar los juegos en los días de trabajo, bajo la pena de pérdida de las mismas ${ }^{22}$. De todos modos el cierre de los establecimientos no resolvía los conflictos que la vagancia y el juego representaban para el gobierno y el control de la sociedad urbana. La instalación de grandes carretas en la plaza para participar del mercado hacía necesario que carreteros y muleros se quedaran en la plaza hasta que cerrara el mercado, donde pasaban horas, durmiendo, bebiendo y jugando. Tema que por otra parte también se encontraba prescrito por los bandos de los gobernadores quienes, para asegurar el abasto de toda la población y evitar el acaparamiento de parte de tenderos y pulperos ordenaron en varias oportunidades:

Que todas las carretas que entrasen en esta ciudad con leña u otras cosas para vender viniesen en derecha para la plaza y en ella estuvieren doce horas para que los vecinos comprasen lo que trajeren y que en esas doce horas no pudieren vender cosa alguna a ningún pulpero ${ }^{23}$.

Testimonios de la época dan cuenta de una multitud de mercachifles o vendedores de bandola ${ }^{24}$ que acampaban en la plaza a fin de asegurarse un lugar para traficar durante el día ${ }^{25}$. Si bien el sector del transporte y del comercio era esencial para la economía de la ciudad, los cientos de jornaleros y mercachifles presentes en la plaza eran, a los ojos de las autoridades esencialmente vagos y personas fuera de la ley. Estas regulaciones respecto a las actividades de los habitantes y los transeúntes de Buenos Aires nos brindan un panorama general del tipo de prácticas habituales en la ciudad, producto de un espacio urbano en auge y de una población heterogénea

21 Ibídem, f. 262.Unos años antes, en 1756, De la Vega explicaba por bando: "Por cuanto se experimenta gran desorden en las corridas de parejas de caballos que acostumbran hacer varias personas no solamente en los días de fiesta (...) si no también en los días de trabajo quitando con este motivo a muchas personas que concurren a ellas de que se ocupen en trabajar para mantenerse". Ibídem, 133.

22 Vertiz amplió la prohibición al sancionar también el cierre de las tahonas y de las canchas luego de las oraciones vespertinas. Bandos..., AGN, Sala IX, Gobierno, 8-10-3, f. 170.

23 Bandos..., AGN, Sala IX, Gobierno, 8-10-2, f. 51-52. Orden que fue reiterada en los años siguientes: Ibídem, fs. 70 340-341, 342; Bandos..., AGN, Sala IX, Gobierno, 8-10-3, fs. 366-367.

24 Se denominaba de bandola o bandoleros a los vendedores ambulantes que circulaban por la ciudad. El nombre se debía al tipo de caja-mostrador que llevaban colgada sobre la espalda conteniendo todas las mercaderías, llamada bandola.

25 Medidas contra los vendedores ambulantes. Autos que se siguen varios mercaderes contra los de bandola. Sobre impedir a estos que no vendan en las calles, Buenos Aires, 1773, AGN, Sala IX, comerciales, $30-09-03$. 
y en continuo movimiento ${ }^{26}$. Ahora bien, estas prohibiciones remitían también a un cierto discurso por parte de los gobernadores que suponía a la vagancia como el peor de los peligros. La figura del vagamundo -aquel que no mantenía ocupación conocida, domicilio fijo ni bienes, quién deambulaba por los "ámbitos de tránsito e intercambio"27, dedicándose al juego y a las borracheras- representaba de algún modo el paradigma de lo incontrolable y por lo tanto el elemento por excelencia a erradicar del entramado urbano.

\section{LA CONCEPTUALIZACIÓN DEL "BIEN COMÚN". LOS TRANSEÚNTES Y LA CATEGORÍA DEL "VAGO" (1740-1760)}

La pretensión por "ordenar" las conductas de la población aparece en la documentación asociada a la consecución del "bien común". Este concepto se hallaba anclado, desde la perspectiva de la elite política dominante, a dos cuestiones centrales. Por una parte en una configuración sociopolítica en la que lo público y lo privado se hallaban profundamente implicados, el mentado "bien común" tendía a identificarse con los intereses particulares y/o corporativos de aquellos agentes encargados de elaborar e implementar las políticas, sin que mediase una contradicción entre dichos términos ${ }^{28}$. Por otra parte, la noción del "bien común" se vinculaba a la imagen que Buenos Aires como "muy noble y muy leal ciudad" 29 debía adquirir y proyectar, es decir la transformación de este ámbito precario en una urbe cada vez más suntuosa. Para ello que

26 La sociedad porteña del período tardo colonial adquirió rasgos más complejos producto del crecimiento comercial y del incremento en las actividades burocrático-administrativas de la ciudad. Al transformarse Buenos Aires definitivamente en el puerto y centro de las actividades mercantiles, los sectores mercantiles se especializaron, perfilándose y definiéndose sus características específicas; los exportadores de frutos del país (cueros, carnes saladas, grasa, astas, sebo, y otros) junto a los comerciantes ligados a los nuevos circuitos económicos en particular del área americana integraron el circulo de los estratos más privilegiados. Incluyó también a los que se dedicaron al tráfico del metal altoperuano, a la venta de "efectos de castilla" (importados) y al tráfico negrero, así como a la alta burocracia. Los sectores medios se dividieron en una capa alta que incluía a los funcionarios de la administración colonial, los profesionales liberales y los religiosos regulares y una capa baja que comprendía a los comerciantes al menudeo, los mercachifles, algunos artesanos y los pequeños y medianos propietarios rurales. Por debajo, se ubicaban los blancos empobrecidos, quienes realizaran "ocupaciones bajas" y la población de color. Según el autor, esta forma de crecimiento demográfico, acompañado por una apertura de los espacios de competencia -en términos burocráticos y mercantiles- acabó agudizando los mecanismos de diferenciación social. Chiaramonte, 2005; Moreno, 2006.

27 Utilizamos dicho término para referirnos a; calles, veredas, plazas, caminos, paseos, tiendas y pulperías.

28 Los conceptos de patria, soberanía, bien común, consulta y consenso fueron entendidos en el periodo de estudio dentro de los parámetros trasladados desde la Península y a partir de la tradición legal española. En este marco, la justicia se convirtió en un medio de ejercer la soberanía y legitimar la autoridad y el papel del monarca como salvaguarda del bienestar de los gobernados requería una política de consenso más que la imposición de la fuerza. La noción de justicia contenía un esbozo general de lo que debía ser el monarca ideal haciendo referencia a la concepción aristotélica del bien común e influido por la interpretación cristiana del mismo. De este modo no sólo el bien común es superior por ser el bien del todo social sino por su esencial índole moral, antes que versar sobre bienes públicos, está construido por la virtud, es decir, por todo aquello que desarrolla de manera positiva y estable al ser humano de acuerdo a su naturaleza profunda. ELLIOT, 2006; VALAREZo DueÑas, 2013, pp. 5-34.

29 En 1716 el Rey otorgó a Buenos Aires el título de "muy noble y muy leal ciudad” en reconocimiento a las campañas militares en la Banda Oriental. NAVARro VIOLA - GregOrIO QUESADA, 1863, p. 666. 
se hacía necesario -al "bien común"- el empleo de los recursos humanos disponibles, así como la eliminación de los indeseables, en particular los vagos ${ }^{30}$.

En España, ya desde mediados del siglo XVII, la condena a la vagancia como peligro social y el valor asignado al trabajo desde lo ideológico aparecían como piedra de toque del desarrollo tanto cultural como económico que la península requería ${ }^{31}$. Estas nociones tuvieron un correlato en la práctica política así como también avanzaron hacia Hispanoamérica de la mano de los funcionarios coloniales. Como venimos observando, en Buenos Aires, a lo largo del siglo XVIII los espacios que denominamos como "ámbitos de tránsito e intercambio" fueron objeto de distintas políticas tendientes a limitar las actividades asociadas al vagabundeo, aunque muchas veces estas intenciones entraron en contradicción con el devenir propio de la vida urbana.

Los gobernadores se ocuparon periódicamente de emitir órdenes en las que se expulsaba a los vagos de la ciudad: "ordeno y mando que dentro de quince días salgan de esta ciudad y su jurisdicción todos los vagamundos y holgazanes que habitan en ella" ${ }^{32}$, o en su defecto se los compelía a conchabarse ${ }^{33}$, particularmente en las tareas de siega. Esto se debía a que Buenos Aires no se caracterizó por mantener un importante caudal de mano de obra disponible para las tareas agrícolas lo que hacía periódicamente peligrar el abasto de la ciudad. Para lograr las cosechas se implementó desde 1743, el conchabo compulsivo por medio de bandos de gobierno, lo que además funcionaba como forma de disciplinamiento ya que pretendía adscribir a los elementos móviles de la sociedad a un espacio preciso $^{34}$. Los funcionarios entendían que había en la ciudad: "gente vagamunda como son negros y mulatos libres, indios y mestizos que puedan servir en el ministerio de la recogida de granos mando que todos los sujetos dichos [salgan a conchabarse], aunque sean oficiales de sastre, zapatero y de otros oficios mecánicos". Por otra parte se prohibía a los dueños de las chacras permitir allí cualquier tipo de juego: "de que se originan pendencias y otras ofensas", con los años, a este mandato se sumó la orden de cierre y cese de actividades de los

30 Vale señalar que la población peninsular instalada en Buenos Aires fue descripta como poco afecta a los trabajos manuales. En 1730 el padre Cayetano Cattaneo explicaba que los únicos que trabajaban en el Río de la Plata eran los esclavos, "el español por más pobre que sea en cuanto llega a las Indias ya no quiere trabajar", Buschiazzo, 1941, p. 199. Un viajero francés que recorrió el Río de la Plata entre 1703 y 1705 explicaba: "Este país sería quizás uno de los más fértiles y abundantes de toda América, si el español que lo habita lo hiciera valer todo lo que vale, pero su pereza es tan grande, que apenas se ocupa de producir las cosas de las que no se puede privar". RíPODAS ARDANAZ, 2002, p. 101.

31 Pietschmann explica que los teóricos del 1600 español fueron pioneros en indicar que la recuperación económica de la metrópolis solo sería posible por medio de una acción estatal capaz de favorecer y de promover el trabajo manual y la producción. PietsChMANn, 1996, p. 22.

32 Bandos..., AGN, Sala IX, Gobierno, 8-10-1, f. 79.

33 Se entiende el término conchabarse como contratarse como sirviente o para labor modesta. El "conchabo" también puede ser definido como un contrato de enganche. En definitiva se trata de un reclutamiento de obreros para trabajar en lugares distintos de los de sus habituales residencias. Es muy frecuente en la realización de determinadas tareas de temporada, como recolección de cosechas (caña de azúcar, tabaco, algodón, yerba mate), y por ello la duración está determinada por el tiempo que aquellas precisen.

34 Ibídem, fs. 18, 23 y 24, 110 y 111, 308 y 309, 344, 375 y 376; Bandos..., AGN, Sala IX, Gobierno, $8-10-2$, fs. 41 y 42, 84 y 85, 131 y 132, 204 y 205, 242 y 243, 298 y 299, 300 y 301; Bandos..., AGN, Sala IX, Gobierno, 8-10-3, fs.41y 42, 1 109, 141, 160 у 161, 193, 223 у 224, 223 у 224, 282 у 283, 397 у 398,441 y 442 . 
"obrajes y obras públicas" a fin de que todos los peones allí empleados salieran a conchabarse ${ }^{35}$.

Si bien los mandatos sentenciaban la existencia de una multitud de "ociosos y haraganes" 36 la orden comprendía a grupos ocupacionales bien definidos como los oficiales y luego los jornaleros de los obrajes, siempre y cuando no fueran españoles. También hay que considerar, por la recurrencia con la que se ordenaba el cese de las actividades en los obrajes y los hornos en tiempos de siega que, probablemente, a aquellos a quienes se obligaba a salir a las chacras les resultaba más conveniente el empleo urbano. Asimismo, los dueños de dichos obrajes tampoco debían ver con buenos ojos el cierre de sus establecimientos y lo mismo debió suceder con los propietarios de las canchas. De esta manera se explica por qué hacia 1753 los bandos incluyeron sanciones tanto para quienes mantuviesen los obrajes en funcionamiento como para quienes ocultasen a los peones en sus casas ${ }^{37}$.

Por otra parte, la proliferación de gente de orígenes y procedencias diversas en la ciudad tuvo un impacto en el funcionamiento de la justicia. El Gobernador Andonaegui se había interesado por realizar un reconocimiento de los medios a partir de los cuales se mantenía esta creciente población así como de los ámbitos en los que los mismos habitaban, en 1746 ordenaba que:

Todos los vagamundos que no tienen oficios de que poderse mantener o que estén conchabados así españoles como indios, mestizos y mulatos salgan de la jurisdicción de este gobierno y no vuelvan a él hasta ahora no ha tenido efecto experimentándose cada día diferentes hurtos que no se pueden averiguar ni coger a los que los ejecutan (...) todos los vecinos y moradores de esta cuidad me darán parte y a las demás justicias de los parajes y casas en que se abrigasen los dichos vagamundos para que sean $\operatorname{presos}^{38}$.

En este documento se volvía evidente la vinculación entre aquellos a quienes no se les reconocía oficio y/o domicilio, es decir ubicación fija en el espacio y los hechos delictivos que se sucedían en la urbe, así como también la participación del vecindario tanto en el "abrigo" de aquellos como en su aprehensión. No obstante, apenas un mes después el Gobernador retomaba el tema precisando que:

... ninguna persona de cualquier calidad o condición que sea compre a ningún indio, negro, mulato ni otra persona española sospechosa forastera cosa alguna de cuyos

35 Bandos..., AGN, Sala IX, Gobierno, 8-10-1, fs. 18, 23-24. En 1750 se sumó al mandato respecto a las tareas de siega, la orden de cierre de todas las "canchas de bolas en donde comúnmente se mantienen jugando y no consientan sus dueños por el tiempo que consideren que puede durar la recogida”. Ibídem, fs. 308-309.

36 Ibídem, f. 376.

37 Bandos..., AGN, Sala IX, Gobierno, 8-10-2, fs. 41-42. También hay que considerar el hecho de que a los propietarios urbanos les representaba un buen negocio el alquiler de cuartos Johnson da cuenta de la extendida práctica de alquiler de habitaciones en la ciudad, dada la presión sobre las viviendas producto del aumento poblacional del siglo XVIII. Reseña distintas posibilidades de arriendo siendo en general una habitación con acceso a un espacio compartido en el patio y tal vez un horno o lugar para hacer un fogón, aunque también explica que muchos se veían limitados a pagar un arriendo para dormir en los patios de las casas. Johnson, 1992 y 2011.

38 Bandos..., AGN, Sala IX, Gobierno, 8-10-1, fs. 96-97. 
mandatos se ha abusado y por esta razón se cometen diferentes hurtos y hallando los que los hacen quien les compre las cosas hurtadas o que se las oculten lo continúan ${ }^{39}$.

El "forastero" aparecía como elemento sospechoso en el entramado socio urbano, causante de robos y hurtos, al mismo tiempo que se denunciaba la connivencia y la participación de los porteños en el desarrollo de hechos delictivos. El 24 de julio de 1747 el mismo Gobernador enviaba el borrador de un bando de buen gobierno para que el Cabildo lo evaluase, en él se ordenaba:

... que todos los vecinos de ella den cuenta de todos los sujetos forasteros a quienes alquilan sus casas y cuartos cuya noticia han de ser obligados los vecinos a dar en la secretaría de gobierno con la individual de dónde son a qué negocios vienen y con qué empleo bajo la conminación de que si no cumplen con lo mandado por este bando se le darán por perdidas dichas casas y cuartos de alquiler ${ }^{40}$.

Notamos que aparecía un interés por conocer, controlar y evaluar el tipo de gente forastera que residía en la ciudad, sus actividades y su modo de vida. Las denuncias previas que señalaban la imposibilidad de aprehender a los responsables de determinados hurtos por su condición de vagos avanzaban ahora a un esfuerzo de parte del gobierno político por lograr un conocimiento y por ende un control más comprehensivo respecto a los habitantes de la ciudad y sus actividades. En consonancia, aquel año Andonaegui solicitó al Cabildo el nombramiento de comisarios de barrio. Dicho funcionario debía llevar un registro con los nombres de quienes vivían en cada casa y bajo qué situación -tanto ocupacional, como estatutaria y familiar ${ }^{41}$. En particular se pretendía llevar un control sobre las personas que entraban y salían de la ciudad. Como contraparte del crecimiento demográfico, se estaba produciendo un cambio en el modo de gobernar la ciudad, caracterizado por la búsqueda de un mayor conocimiento de las personas y de sus actividades. El 22 de enero de 1748, finalmente el Cabildo nombró a los comisarios ${ }^{42}$. Sin embargo, apenas unos meses después de la designación, el Ayuntamiento comenzó a denunciar ciertos abusos que los comisarios estarían cometiendo sobre el vecindario. Señalaban que:

Excedían la comisión que se les ha conferido tomándose jurisdicciones que ni el Cabildo ni el Gobernador les ha conferido por que está informado que incomodan al vecindario haciéndoles abrir las puertas y otras exhortaciones que causan notable escándalo ${ }^{43}$.

Se debatía en particular sobre cuáles eran las jurisdicciones y las prerrogativas de los comisarios y cuál era su relación respecto al accionar de los alcaldes del Cabildo

\footnotetext{
39 Ibídem, fs. 134-135.

40 AGN, 1931, 267-270. El 8 de agosto de ese mismo año, el texto se publicó en forma de bando de buen gobierno, con la sola modificación de las penas que se aliviaban notablemente ya que, de la pérdida de las casas se pasaba a una multa de 25 pesos. Bandos..., AGN, Sala IX, Gobierno, 8-10-1, f. 141.

41 Konetzke, 1987, p. 90.

42 AGN, 1931, pp. 321-323, 324-326, 326-329.

43 Ibídem, p. 368.
} 
en tanto jueces en primera instancia. Con el establecimiento de los nuevos funcionarios, el Gobernador inhibía el accionar de los capitulares señalando el manejo de las causas judiciales a los comisarios, lo que para el Cabildo resultaba "en gravísimo perjuicio de la causa pública y buena administración de la justicia" ${ }^{4}$. Si tenemos en cuenta que los miembros del Cabildo llevaron casi un año dilatando el nombramiento de los nuevos funcionarios podemos sospechar que, más allá de los abusos denunciados por los vecinos, los alcaldes no tenían interés en perder sus prerrogativas y su autoridad en cuanto al funcionamiento de la justicia y del gobierno como tampoco el pago que recibían por los costos de los procesos que atendían, de modo que el cargo fue desestimado y no volvió a implementarse hasta la llegada a la gobernación de Juan José Vertiz en $1770^{45}$. Si bien la preocupación de Andonaegui por el orden y el control de la población en la ciudad se encontraba anclada en una realidad concreta, tal como explica Amores Carredano el que las normas jurídicas logren modificar o corregir lo logre el orden social que defiende quien la ha dictado dependerá esencialmente del poder real de que disponga su autoridad para demandar el cumplimiento ${ }^{46}$. En un contexto en el que nuevos y desconocidos sujetos circulaban por la urbe, el funcionamiento de la justicia se vio afectado y frente a los problemas en torno a las jurisdicciones correspondientes a los encargados del gobierno y la justicia, las acusaciones en torno al incremento de los desórdenes en la ciudad recayeron en aquellos elementos considerados "incontrolables", es decir quienes no tenían oficio, bienes y sobre todo quienes no contaban con una ubicación fija en el espacio de la ciudad ${ }^{47}$.

44 Ibídem, p. 369.

45 Los Cabildos representaron la "unidad local de gobierno político" en un contexto en el que al no existir un cuerpo orgánico de leyes que rigiera la existencia de estos órganos, la organización se basó en la costumbre y en las ordenanzas sancionadas para cada ayuntamiento. Los mismos cumplían con diversas funciones; legales, políticas, fiscales y administrativas, se ocupaban de la distribución de tierras, el cuidado edilicio y sanitario de la ciudad, la conservación e inspección de cárceles y hospitales, el control del abasto, la regulación del comercio, la fijación de precios y salarios, la protección de los pobres y de los menores, la atención de enseñanza primaria, la organización de fiestas laicas y religiosas, la mantención del orden público, es decir lo que "configuraba el gobierno 'por menor' de la ciudad”, TAu Anzó́tegui - Martiré, 2006, p. 97. Por su parte el Gobernador tenía a su cargo la promulgación de autos y bandos de gobierno, el envío de informes al Virrey o al Rey y la presidencia de los Cabildos y en ciertos casos el reparto de encomiendas, tierras y mercedes. En relación a la regulación de los asuntos urbanos, vale aclarar que la misma era ejercida tanto por los Cabildos como por las autoridades Reales y resulta difícil señalar la frontera entre aquello que correspondía a cada uno de ellos. El derecho público español no acostumbraba a indicar con absoluta precisión los poderes de los organismos políticos. Lo mismo conducía a la formación de un cúmulo de normas que eran especiales a una zona y no aplicables a otra y que constituían el estatus de un funcionario. A lo que debemos añadir el localismo jurídico en cada caso dado que, como señalamos, el "derecho indiano" no representaba un mero reflejo de las disposiciones metropolitanas sino, múltiples construcciones locales en las que confluían diversos ordenes jurídicos, TAu ANZoÁtegui, 2004. La jerarquía entre dichos órdenes dependía de las áreas de la vida social regulada y del juego de los distintos poderes jurisdiccionales y normativos existentes. En cada caso, los márgenes de maniobra dependían de la capacidad política de los agentes, por lo que las relaciones de poder local y la coyuntura específica adquirían un peso importante, LORANDI, 2008.

46 Amores Carredano, 2004, p. 103. En 1754 Andonaegui volvió a insistir en la necesidad de contar con alcaldes de barrio. Luego de varios acuerdos en que el tema fue transferido, los capitulares explicaron al Gobernador que no tenían por conveniente el nombramiento de dichos alcaldes dado que: "la experiencia ha mostrado en otra ocasión que se nombraron el que más servían de acrecentar disturbios que de refrenarlos ni contenerlos", con lo que el tema fue nuevamente abandonado. AGN, 1926, pp. 475-477 y 492-495.

47 El estado edilicio de la cárcel era calamitoso y esa situación facilitaba las huidas de los presos. En 1760 esto funcionó como detonante para que se desatase una disputa entre los alcaldes del Cabildo y el 
No obstante, los denominados "vagamundos" no fueron los únicos individuos sujetos a periódicos mandatos de expulsión.

\section{EXTRANJEROS, ENTRE LA AMBIGÜEDAD Y EL OPORTUNISMO (1740-1760)}

Si bien, a lo largo del siglo XVII los extranjeros ${ }^{48}$-principalmente portugueses, pero también franceses, ingleses y holandeses- se desenvolvieron en el espacio rioplatense y se integraron a la elite y a la sociedad local, el arribo de españoles -debido a las posibilidades tanto burocráticas como comerciales que la ciudad empezaba a proveer-, marcó el desplazamiento de los extranjeros de ciertos espacios de poder ${ }^{49}$. En 1740 el gobernador Salcedo sancionó la expulsión de todos los extranjeros de la ciudad, orden que fue contestada por el Procurador General quien señaló los perjuicios que la medida implicaba al "bien público, dado que entre las personas sujetas a expulsión se encontraban muchas ya avecinadas y con oficios mecánicos útiles" ${ }^{50}$. Por esta razón la orden fue limitada a los solteros, mientras que los casados podían permanecer dado su arraigo en la sociedad porteña, ya fuera por vínculos económicos y/o familiares, siempre y cuando no participasen en actividades comerciales.

No obstante, el desarrollo de hostilidades intermitentes entre las Coronas española y lusitana, así como el avance portugués en la banda oriental del Río de la Plata, llevaron a Ortiz de Rozas a reiterar los mandatos de expulsión de extranjeros, con especial énfasis en la población portuguesa ${ }^{51}$. Sin embargo, en 1743 los miembros del Cabildo nuevamente impugnaron el mandato, realizando una defensa en pos de la permanencia en la ciudad de los extranjeros que se empleaban en oficios mecánicos ${ }^{52}$. En una ciudad con escaso caudal de mano de obra, no solo para las tareas agrícolas

\footnotetext{
Alguacil Mayor, dado que los primeros consideraban que correspondía a dicho funcionario financiar las obras necesarias para evitar las huidas. El alguacil optó por recurrir al Gobernador acusando a los Alcaldes en su calidad de jueces. Señalaba que las huidas estaban motivadas por "la gran demora que tienen las causas por los delitos criminales de forma que por falta del pronto y debido despacho (...) la larga detención de estos reos en las prisiones los que motivados de esto escalan con frecuencia las cárceles haciendo fuga". Bandos..., AGN, Sala IX, Gobierno, 8-10-2, f. 210. Los alcaldes elaboraron su descargo señalando que “....siendo como ya se declaró mucho lo que ha crecido el gentío y especialmente de estas gentes sin bienes ningunos, ni habitación fija ni conocida pues trabajan cuatro días con uno y otros tantos o menos con otros vagando de esta suerte a su libre albedrío, no teniendo bienes que perder ni aspirando a mayores progresos o adelantamientos se contentan con pasar el día y por la poca honra y vergüenza que les asiste se dan a la embriaguez, andan algo extraviados de las calles principales de la ciudad". Ibídem, fs. 215 y 218.

48 En Hispanoamérica, el fenómeno migratorio fue regulado y solo se permitía arribar allí a sujetos provenientes de las Coronas de Castilla y Aragón que pudieran probar limpieza de sangre, MöRNER, 1992. Todo aquel que no cumpliera con dichos requisitos era calificado como extranjero y teóricamente se le prohibía pasar a las Indias. No obstante, el cumplimiento de este precepto fue obviado recurrentemente tanto por vías legales -la licencia, la composición o la naturalización- como extra legales. Al ser la nacionalidad española un concepto difuso, vago y cambiante, tanto en España, como en América, la diferenciación entre extranjeros y naturales provino más de un proceso social que legal y el acceso a dichas categorías se lograba o no a través de mecanismos de dicha índole, Herzog, 2006.

49 Socolow, 1991, p. 23.

50 Tau Anzó́tegui, 1992, p. 282.

51 Bandos..., AGN, Sala IX, Gobierno, 8-10-1, fs. 21-22 y 23-24.

52 Tau Anzó́tegui, 1992, p. 284.
} 
sino también para los oficios mecánicos el aporte de los extranjeros era considerado central ${ }^{53}$.

Se hacía presente el poder de los miembros del Cabildo porteño a la hora de sancionar qué resultaba beneficioso para el "bien común", en detrimento de una orden de expulsión emanada por el poder metropolitano que contradecía la costumbre de aceptación e incorporación de todos aquellos que representaran una utilidad al desarrollo de la ciudad. Resulta evidente aquí el valor que se le otorgaba al trabajo y/o la ocupación de los sujetos en cuanto a su incorporación al entramado social, no solo en relación a su "utilidad", sino también porque la ocupación conllevaba el conocimiento público de los sujetos, su lugar de habitación, sus vínculos y el origen de sus ingresos, lo que los posicionaba socialmente por encima de los "vagamundos", aunque esta percepción fue variando con los años. Más allá de las pujas entre el Gobernador y el Cabildo los extranjeros no solo no abandonaron la ciudad sino que continuaron arribando, mientras que los gobernadores mostraron un periódico interés en su expulsión, reiterándose los mandatos en este sentido ${ }^{54}$.

Las sanciones a determinadas prácticas que analizamos, la condena a la vagancia y de algún modo el "rescate" propuesto hacia aquellos extranjeros empleados en oficios mecánicos dan cuenta de un gobierno que tomaba conciencia del carácter del crecimiento que transitaba la ciudad y buscaba de alguna manera encauzarlo en virtud de los conflictos y los requerimientos efectivos que dicho crecimiento imponía. En el caso del conchabo compulsivo hay un claro interés por sostener tanto el abasto urbano como a los propios hacendados de la campaña bonaerense de cuyos intereses también dependía el funcionamiento de la elite urbana, al mismo tiempo que se ponía en juego el valor social del trabajo. Sin embargo el mismo crecimiento demográfico y comercial de la ciudad promovió una competencia por los espacios económicos en la que se jugaron diversas percepciones en torno a la sociedad urbana y al "bien común" y la actitud por parte de la sociedad local hacia la permanencia de los extranjeros sufrió transformaciones cuando sus intereses comerciales se vieron afectados. El desarrollo del comercio al interior de la ciudad fue un terreno de disputa en el que se entrecruzaron los intereses particulares de determinados actores, las necesidades y las posibilidades que el crecimiento poblacional contraía para el devenir de la ciudad y ciertos propósitos regulatorios por parte de las autoridades, que no estuvieron exentos tampoco de la búsqueda de beneficios a título corporativo y/o individual.

En este sentido, las panaderías en la ciudad fueron objeto de debate y/o disputa. En 1750 el Cabildo solicitó al Gobernador Andonaegui "que si entre los dichos panaderos hubiere algunos extranjeros se les notifique (...) y en cumplimiento del bando mandado promulgar por su señoría arreglado a la ley de indias salgan de esta

53 Según el funcionario, los extranjeros brindaban a la ciudad: "El beneficio de una regular arquitectura en la construcción y fábrica de las casas y habitaciones; en la carpintería muchos adelantamientos y novedades muy propicias no solo en lo correspondiente a los edificios, sino a los trastes del uso y manejo común de las casas (,) y instrumentos músicos (;) en el ejercicio de herrería es igual el adelantamiento y no menos lo es en sastrerías, zapaterías platerías y los demás oficios mecánicos”, en TAU AnZoÁtegui, 1992, p. 284.

54 A lo largo de los años, todos los Gobernadores publicaron bandos de expulsión: Bandos..., AGN, Sala IX, Gobierno, 8-10-1, fs. 36-38, 67-68, 79-80, 85-86, 140-141, 153-154, 263-265, 270-272, 306-308; Bandos..., AGN, Sala IX, Gobierno, 8-10-2, fs. 100-102, 248-251, 252-253, 254-255, 281-282, 352-353, 355; Bandos..., AGN, Sala IX, Gobierno, 8-10-3, fs. 62, 63, 64-65, 92, 198, 401. 
ciudad" ${ }^{55}$. Si bien hemos mostrado cómo los capitulares actuaron en defensa de la permanencia de extranjeros cuando por sus actividades y/o vínculos se juzgaron provechoso al "bien común" ${ }^{56}$, hacia 1750 el acceso a lugares importantes dentro del comercio y la burocracia fue paulatinamente monopolizado por españoles, ya fueran enviados por la Corona como los que llegaban a Buenos Aires por sus propios medios con contactos establecidos con figuras importantes de la sociedad local. Los miembros del Cabildo -pertenecientes ellos mismos a estas redes de poder político y económico-, comenzaron también a cambiar su posicionamiento en cuanto a las actividades económicas que los extranjeros desarrollaban en la ciudad.

\section{ELAUGE DEL COMERCIO INTERNO Y LOS CONFLICTOS DERIVADOS (1760-1776)}

En 1760, el Procurador General Francisco Cabrera presentó un memorial en el que expresaba su preocupación porque se estarían haciendo cargo de la producción de varios artículos de consumo indispensable "personas extranjeras":

... pues los panaderos que fabrican este pan francés son por lo común extranjeros se mande dar cumplimiento a las leyes municipales que prohíben el asiento y habitación de los extranjeros en las ciudades de estos reinos ${ }^{57}$.

Observamos la fuerte intención de hacer cumplir con los mandatos de expulsión, que acusaban ahora nuevas razones:

... porque desterrados de este modo a los extranjeros, no solo se remediará el mal a que su codicia los precipita, sino aquella ilícita ganancia que sufren semejantes ejercicios la repartirían los de este país y tendrá esta ciudad el consuelo de gozar de la abundancia que el cielo le ha concedido y de que la ha privado la tiranía de los panaderos al mismo tiempo que vea a sus hijos disfrutar de la vitalidad que ofrece la fábrica y venta del pan ${ }^{58}$.

Vemos cómo se entablaba una profunda diferencia en torno a quién corresponderían lo beneficios que la ciudad ofrecía y se dejaba entrever una toma de conciencia de parte de los capitulares en torno a las posibilidades comerciales concretas al interior de la ciudad ${ }^{59}$. Ahora bien, si durante años se había incorporado a los extranjeros

55 Bandos..., AGN, Sala IX, Gobierno, 8-10-1, fs. 306-308.

56 Por ejemplo ver: Acuerdo del 05 de marzo de 1748 y el 27 de enero de 1750 se presentan dos memoriales, uno por Juan de Acota maestro tornero y Antonio Carridia maestro de armero y el único para poner granos a la artillería; "para que no salgan de la ciudad, en cumplimiento del bando de expulsión de extranjeros, por ser útiles a la ciudad" y el otro por Manuel Ferreira, maestro de sastre de nación Lusitana, sobre el que el Cabildo explica: "es útil y provechoso al bien común de la república y es hombre conocido, sosegado y de buenos procedimientos". AGN, 1931, pp. 360, 540-542.

57 Bandos..., AGN, Sala IX, Gobierno, 8-10-2, f 248.

58 Ibídem, f 249.

59 Respecto a la idea de "tiranía”, cabe señalar que en el año 1734 el Regidor De La Palma Lobaton utilizó el mismo calificativo para acusar a los médicos extranjeros Roberto de la Fontaine y Roberto Young, 
en la ciudad y en las diversas actividades económicas de la misma, ¿qué es lo que provocó la aparición de estos escritos en dónde se posicionaba a "dichos extranjeros" como perjudiciales para el vecindario? En este punto es importante preguntarnos para quién eran relevantes las observaciones elaboradas por el Procurador General. Vale señalar que Cabrera era un comerciante español que llegó al Río de la Plata en 1754 con el cargo de Asentista de víveres del Ejército Real ${ }^{60}$, con lo cual podemos entender cómo sus propios intereses y los de su familia y asociados, se veían afectados por los hechos que estaba denunciando ${ }^{61}$.

Recordemos, la regularidad con la que los comerciantes combinaban sus actividades económicas con cargos burocráticos, en general adquiridos en remate lo que les aseguraban el acceso a tratos comerciales más favorables ${ }^{62}$. Durante estos años, ciertos espacios burocráticos y mercantiles que anteriormente pudieron estar abiertos a quienes tuvieran el caudal económico para participar, fueran o no extranjeros, pasaron a ser monopolizados por españoles recién llegados que lograron consolidar su poder en el plano local, utilizando la orden de expulsión en su competencia por los beneficios que proporcionaba el comercio interno. A su vez la demarcación de límites necesaria para el cumplimiento del Tratado de Permuta, no estuvo exenta de conflic$\operatorname{tos}^{63}$. Luego de la anulación del mismo en febrero de 1761, el conflicto bélico en el Río de la Plata, se había desatado nuevamente por lo cual, el clima político se volvía más propicio para la limitación de las actividades económicas de los extranjeros en la zona.

Sin embargo, consideramos que esta documentación y el consecuente bando que reiteraba la orden de expulsión ${ }^{64}$, estaban expresando un cambio de posición en relación al tema de los "extranjeros" que no solo derivaba de la situación bélica. Las transformaciones que se produjeron en la sociedad como producto del crecimiento de las posibilidades económicas fueron cambiando las reglas del juego social. Con ellas se amplió el margen de acción para que representantes de ciertos intereses comerciales tuvieran el margen necesario para elaborar políticas más restrictivas y así proteger

aduciendo que los mismos "tiranizan" al pueblo por los precios de sus boticas, ZABALA - De GANDIA, 1937, p. 97. El término también fue utilizado por los vendedores de bandola para referirse a los tenderos que querían limitar su actividad, Medidas contra los vendedores ambulantes. Autos que se siguen varios mercaderes contra los de bandola. Sobre impedir a estos que no vendan en las calles. 1773, AGN, Sala IX, comerciales, legajo 8, expediente 4, 30 - 09 - 03, f. 10.

60 Socolow, 1991, p. 76

61 Para 1778, Francisco Cabrera ocupó el cargo de Contador Mayor del Real ejército y del Virreinato (Ibídem, p. 106). Además de él, otros tres de sus compañeros en el cuerpo durante 1761, Alonso García Zuñiga, Francisco Soloaga y Diego Mantilla y los Ríos fueron parte del grupo de comerciantes que en 1767 colaboraron con Manuel Basavilbaso en su presentación al consejo de Indias por la libre internación de artículos al Alto Perú. AGN, 1927, pp. 549-553.

62 Gelman, 1989 y Socolow, 1991.

63 España, acosada por las guerras europeas y por una profunda crisis económica y política, firmó en 1750 el Tratado de Permuta con Portugal que entre otras cosas, disponía la permuta de Colonia de Sacramento por el territorio ocupado por siete pueblos guaraníes de las reducciones jesuíticas. Sin embargo, el tratado no fue bien recibido en los territorios americanos. Luego del infructuoso trabajo de los demarcadores oficiales, de las distintas quejas y pedidos de los funcionarios locales y de los levantamientos que acabaron en lo que se denominó la guerra guaranítica, en febrero de 1761 el Tratado fue anulado y el Gobernador Cevallos se dispuso a retomar Colonia por la fuerza. QUARLERI, 2009, pp. 91-95.

64 Bandos..., AGN, Sala IX, Gobierno, 8-10-2, fs. 252-253. 
sus negocios. Así, los mercaderes y los burócratas locales pugnaron por el control del comercio urbano, dentro del cual se sentían con plenos derechos ${ }^{65}$.

Respecto a los extranjeros en la ciudad, unos meses después de que fueran emitidas estas disposiciones, Cevallos ordenó por bando que dieran razón por escrito del lugar de donde provenían, las causas por las que estaban en la ciudad, el tiempo de residencia, el oficio que desempeñaban, si eran casados o solteros y en que calle y casa residían, con el objeto de indultar a aquellos "en quienes concurran las cualidades y circunstancias que las leyes previenen" ${ }^{66}$, y de expulsar a aquellos que no. El Gobernador ajustaba el control en torno los extranjeros a los que se permitiría residir en la ciudad, a diferencia de los mandatos anteriores en los que la expulsión había tomado una forma más indiscriminada ${ }^{67}$.

Pero no fueron los capitulares los únicos en reconocer las posibilidades económicas que proporcionaba Buenos Aires. La floreciente ciudad atrajo a multitud de comerciantes de distinto rango que también se apropiaron, tanto del espacio urbano como del comercio en su interior. En 1773 un grupo de comerciantes de tienda inició acciones legales para eliminar y/o limitar a la actividad de los mercachifles ${ }^{68}$ que deambulaban por la ciudad poniendo en evidencia la masividad de dicha práctica. En su primer escrito denunciaban que aquellos, "dilatándose por las calles, casas, plazas, quintas y extramuros de esta ciudad no dejan comprador alguno que llegue [a las tiendas]"69. Manifestaban que la multitud de vendedores por las calles representaba una seria amenaza para su supervivencia, lo que vulneraba "la justicia legal que atiende a la dirección del bien común" ${ }^{\text {"70 }}$. A sus ojos, los mercachifles representaban una seria amenaza al "público" siendo capaces de "aniquilarlo y de desterrar enteramente las tiendas que con su supresión acarrearía la ruina de muchos caudales, créditos y familias que enteramente viven y se alimentan del ingreso que al día se logra" ${ }^{\text {", }}$, asimismo denunciaban que:

No satisfechos con ocupar el centro y extramuros para sus ilícitos tratos se apoderan en emulación de los principales puestos de la plaza, pernoctando muchos de ellos, por

65 El tema de las panaderías reapareció en 1773. Manuel Basavilbaso como Procurador General denunció que la existencia de panaderías en la ciudad en manos tanto de "vecinos como forasteros y muchos de ellos extranjeros" causaban "graves inconvenientes y perjuicios", dado que se habría producido una especie de estanco en el rubro "despojado insensiblemente a las familias pobres de este único arbitrio (...) al mismo tiempo que aumentan sus utilidades hasta un término excesivo". Se ordenaba, para protección de los pobres el cierre de todas las panaderías en la ciudad. No obstante dos meses después el Cabildo denunciaba el incumplimiento de dicha orden, Bandos..., AGN, Sala IX, Gobierno, 8-10-3, fs. 284-287,301-303.

66 Bandos..., AGN, IX-8-10-2, f. 282.

67 Las políticas que siguieron en relación a la presencia de extranjeros en la ciudad ya no estuvieron dedicadas a la expulsión indiscriminada sino, por el contrario buscaban la realización de padrones en los que quedasen establecidas las características de cada uno de ellos a fin de evaluar los beneficios que podían aportar a la ciudad y en este sentido si se les permitía o no permanecer en ella. Por ejemplo: Bandos..., AGN, IX 9-810-3 fs. 62 y 198.

68 También llamados vendedores ambulantes y/o de bandola.

69 Medidas contra..., 1773, AGN, Sala IX, comerciales, 30 - 09- 03, f. 19.

70 Ibídem, f. 1.

71 Ibídem, f. 22. 
escoger el más oportuno y próximo a la concurrencia de gentes que de mañana van a ella a comprar el diario alimento ${ }^{72}$.

Los vendedores de bandola, respondían a dichas acusaciones señalando que la venta ambulante representaba un escalón habitual en la carrera del comercio, trayectoria que olvidaban los tenderos al realizar la denuncia. Se preguntaban los demandados si era realmente en beneficio de la "república" el que:

Por conservarse en superior auge, un corto número de individuos, queden los restantes sus esclavos y mendigos (...) y si será armonía de buen amor al pueblo que cortándole el paso a estos necesitados y en ellos a sus respectivas obligaciones lleguen a infestarlo con fraudes, latrocinios, homicidios y otros cuidados poniéndolos en un continuo sobresalto y desvelando a los jueces (...) debiendo aplaudir una cosa tan santa y honesta, cual es el vivir cada uno por su sudor, gozarse y ayudarle según sus medio lo reprenden y quieren desterrar! ${ }^{73}$.

Se hace visible el revés de la trama en torno al valor del trabajo en la sociedad porteña colonial, así como las diversas aristas desde las cuales se podía conceptualizar a la vagancia. Señalábamos anteriormente que la ocupación nocturna de la plaza era concebida por parte de las autoridades como un hecho pernicioso a ser controlado. No obstante, tal como venimos observando, la ocupación de dicho espacio en distintos momentos de la jornada era parte de la organización cotidiana del comercio interno y el abasto de la ciudad.

Ahora bien, la carrera comercial a la que hacían mención los bandoleros representaba en si un ámbito de competencia. Socolow advierte, en cuanto al grupo de comerciantes en general, que si bien podían peticionar y pleitear en conjunto había también muchas escisiones dentro del grupo determinadas por el tipo de actividad que cada uno desempeñaba; mayoristas, minoristas, pulperos, bandoleros. Dentro de cada uno de estos grupos existía -de acuerdo a la autora- un fuerte sentimiento de solidaridad y la percepción de posibles amenazas debidas a cambios de políticas, alentados por otro de los grupos. Cada sector veía en el grupo inmediatamente inferior en la escala una posible amenaza.

En la reacción de los tenderos nuevamente nos encontramos frente a una noción del "bien común" que se debatía/componía tanto por principios generales como de intereses particulares. Los bandoleros otorgaban el valor del bien común a un tipo de tráfico más accesible para las familias pobres de la ciudad ${ }^{74}$, así como a la noción de que la venta ambulante representaba, "el medio más apropiado y común para llegar a la carrera de comerciantes los españoles pobres que vienen a las indias, siendo constante que el auge y conservación de estos países es el comercio" ". No obstante para los tenderos el "bien común" radicaba en limitar la multitud de tratantes de bandola

72 Ibídem, fs. 2-3.

73 Ibídem, f. 11.

74 "Que nuestro comercio sea utilísimo al publico es innegable si se considera que además de la moderación en precios aliviamos a las casas que no tienen sirvientes, excusándoles de que para una menudencia continua de sus labores y menesteres salga a la calle de la vigilancia de sus padres la hija doncella". Ibídem, f. 12.

75 Ibídem, f. 108. 
que circulaban por la ciudad, para lo que sugerían que los mismos fueran compelidos a salir a las chacras a emplearse como labradores -destino históricamente propuesto para aquellos sujetos caratulados como vagos y holgazanes y/o negros libres, indios, mestizos y mulatos con o sin oficio reconocido. Sin embargo, los bandoleros se reconocían a sí mismos en una posición social diferente a la de los grupos afectados por el conchabo obligatorio. Señalaban que el ejercicio de la bandola era el medio para llegar a ser mercader en toda América y que el comercio:

... es el giro más general en ella [América] y de que penden su conservación y excelencias, distintivo al mismo tiempo de las ocupaciones viles de negros, mulatos e indios abundantes en superior grado, que reconocen en ello la granjería de los españoles para el respeto y freno contra sus maquinaciones de rebelión ${ }^{76}$.

Los mercachifles se ocuparon en defender su "calidad" como parte del vecindario, resaltando para ello el ser: "unos mozos honrados y europeos muy aplicados a hacer fortuna sin que se les note de mala conducta, ni por otro gravamen de los que causan los pobres vagabundos y gente licenciosa" 77 , que tenían al bandolerismo como el medio más acertado para hacer carrera en el comercio. No fue casual que los vendedores de bandola buscasen distanciarse del apelativo de vagabundos, así como de proveer testigos que reconociesen sus domicilios y procedencias ${ }^{78}$.

Los casos reseñados, tanto el de los panaderos como el de los mercachifles, nos enseñan un contexto específico a partir del cual son visibles tanto el poder de los funcionarios/comerciantes a la hora de defender sus prerrogativas como el modo en que sectores sociales ajenos a los entramados de poder -en particular los bandolerosutilizaron los argumentos gubernamentales para defender sus derechos. Los casos nos hablan también de una ciudad cuyo crecimiento económico y demográfico planteaban un aumento en la demanda de bienes que fue rápidamente aprovechado por la multitud de comerciantes que arribaban a Buenos Aires. Respecto a los mercachifles, si bien desconocemos cuál fue la resolución del pleito, en 1775 el grupo realizó una presentación ante el Cabildo solicitando una rebaja en el monto que pagaban diariamente por mantenerse en la plaza en el que además, señalaban la continuidad del pleito $^{79}$. Lo que abre otra cuestión a la problemática del desarrollo urbano de Buenos Aires. Más allá de las quejas de los tenderos, en un ámbito en el que la "cortedad de propios" era la norma, el aporte diario de los bandoleros era sin duda un argumento a su favor.

Mientras los actores que participaban del comercio y del gobierno local se debatían en torno a sus prerrogativas y derechos, los tópicos relativos a la ocupación/trabajo y a la ubicación en el espacio de la creciente población porteña, así como los intentos por lograr una administración de la justicia más sistemática continuaron preocupando a los gobernadores y en particular a aquellos identificados con los lineamientos borbónicos.

\footnotetext{
76 Ibídem, f. 29.

77 Ibídem, f. 82.

78 Ibídem, fs. 82-111.

79 AGN, 1928, pp. 248-250.
} 


\section{A MODO DE CIERRE: DE LA REITERACIÓN A LA CENTRALIZACIÓN (1770-1776)}

Juan José de Vertiz y Salcedo ocupó el cargo de Gobernador del Río de la Plata entre 1770 y 1776 y fue un claro representante de la política borbónica en la región, particularmente en lo referido a la regulación y el control de las actividades de la población en la ciudad ${ }^{80}$. El principal objetivo de los ilustrados españoles fue la reactivación económica de la metrópolis y fue esto lo que impulsó todos los planes reformistas que se propusieron desde y hacia el campo estatal en la segunda mitad del siglo XVIII. Sin embargo, tal como explica Pietschmann los ilustrados reconocieron que para llevar a cabo el programa de reformas -en sus vertientes fiscales y productivas- requerían de la participación activa de la población. Paradójicamente también advirtieron que lo mismo solo se lograría por medio de un esfuerzo sostenido dirigido a mejorar su nivel de vida, lo que al mismo tiempo solo resultaría posible por medio de una revitalización de la economía que permitiera incrementar el bienestar de la sociedad $^{81}$. Estos planes requirieron políticas destinadas a reformar no solo el campo económico y la administración del Estado, sino también el cultural y el social, por lo tanto, el estímulo a la producción y al comercio, el desarrollo urbano y la organización de la población y de sus actividades fueron centrales.

Las reformas de la nueva dinastía pretendían "imponer un nuevo modelo sociocultural que implicaba el impulso regio en campos de la vida social de los cuales, hasta la fecha, las corporaciones eclesiásticas y los gobiernos municipales habían sido los responsables casi exclusivos" ${ }^{82}$. Un ejemplo de estas nociones está dado por la organización de los bailes de máscaras en carnaval por parte de Vertiz que buscaban, entre otras cosas, marcar la norma respecto a las relaciones entre hombres y mujeres ${ }^{83}$.

Respecto específicamente a la organización de la población y de sus actividades, los tópicos que más habían preocupado a sus antecesores, como las corridas de caballos, la portación y el uso de armas prohibidas, las sanciones a los juegos, los horarios de cierre de tahonas, tiendas y pulperías y la iluminación de sus portales, la expulsión

80 Cabe aclarar que tanto Cevallos como Bucareli, también representaron los intereses borbónicos en el área, el primero muy involucrado en las campañas militares en la banda oriental y el segundo a cargo de la ejecución de la expulsión de la Compañía de Jesús en el Río de la Plata y Misiones.

81 Pietschmann, 1996, pp. 22-24.

82 LeMPÉRIÈre, 2000, p. 203. Algunas de las medidas de Vertiz -en consonancia con el regalismo borbónicotendieron a limitar ciertos hábitos religiosos de los porteños, prohibió las "disciplinas de sangre" por las calles durante las pascuas, limitó el alcance de los lutos, cuestionó las intenciones de los confesores durante la extremaunción e hizo cumplir la Real Cédula que recortaba la cantidad de iglesias que podían servir como asilo a los delincuentes. Bandos..., AGN, Sala IX, Gobierno, 8-10-3, fs. 274-275, 330-331, 377-378, 406. Avanzando sobre los hábitos de los porteños fue el primero en sancionar y regular la forma en que los hombres y las mujeres de la ciudad debían tomar sus baños en el río, Ibídem, fs. 262-263.

83 Don Bartolomé Raimundo Muñoz, interventor de la real renta de correos, explicaba que "no era creíble que en una sala tan bien dispuesta sin más piso que el de su suelo y el de la gradería corrida a las paredes, con una iluminación superabundante pudiese haber exceso sin que fuese notorio a todos, ni tampoco es presumible que en las providencias tan escrupulosas como las que fue público que tomo el señor Gobernador (...) no se permitiese gentes paradas porque no hubiese confusión entre uno y otro sexo". Información sobre los bailes de mascaras, producida a raíz de los bailes de carnaval, Buenos Aires, 1773. AGN, Sala IX, hacienda, legajo 6 , expediente $105,32-8-5$, f. 10. 
de vagos fueron minuciosamente compilados en el primero de los tres bandos de buen gobierno por él publicados y dejaron de ser reiterados en los particulares ${ }^{84}$. Lo mismo, implicó un cambio en la forma de legislar la vida cotidiana de los "estantes y habitantes" de la ciudad centrada en las intenciones de parte de Vertiz por institucionalizar el discurso legislativo por medio de la construcción de un aparato estatal que mediatizaba la intervención de los Gobernadores en la política del día a día al mismo tiempo que limitaba la participación de los vecinos en el ordenamiento de la vida cotidiana. Es en este sentido que la relación tanto del Gobernador como de los alcaldes del Cabildo -en tanto encargados de la justicia en primera instancia- con los distintos "desórdenes" sancionados por los bandos antecedentes pasó, en 1772 a estar minuciosamente mediatizada por los comisarios de barrio designados por el mismo Vertiz $^{85}$

Señalaba el Gobernador "la urgentísima necesidad de multiplicar personas que celen las ofensas a dios, pecados públicos, robos, muertes, heridas", así como el hecho de que los jueces ordinarios no daban abasto combinando las tareas pertinentes a la debida administración de la justicia y su "facultad de aprehender infraganti a cualesquiera agresor como que por la vasta extensión de este pueblo se hace inverificable por los mismos jueces ordinarios", lo que ya había sido señalado y debatido diez años antes. De este modo, reconociendo la insuficiencia de los mecanismos existentes para limitar los desordenes dado el continuo crecimiento demográfico y espacial de la jurisdicción, el Gobernador se determinó a "imitación de la capital de este reino y otras en nombrar diferentes comisionados repartidos por islas en todo el ámbito de ella" 86 . Vertiz se ocupó de enumerar minuciosamente estas cuestiones, "para que cada uno de

84 Tau AnzoÁtegui, 2004, pp. 272-277. Respecto a las armas prohibidas, por ejemplo, dedicó tres largos capítulos a precisar y especificar la prohibición. Señalaba que las armas prohibidas eran: "dagas, puñales, rejones, cuchillos, macanas", realizaba una excepción respecto a los carniceros en tanto su oficio requería por definición el uso de cuchillos e indicaba que: "solamente se permite que cuando salgan al campo lo puedan llevar [en] vaina amarrada al lomillo". Por último, comprendiendo la posibilidad de guerra o de ataques de parte de los indígenas se permitía a los vecinos la posesión de armas de fuego con fines defensivos, como son "carabinas, pistolas de arzón y generalmente las que tengan cuatro cuartas de cañón", quedando absolutamente prohibido el que "puedan tener ni traer consigo otra arma corta de fuego". TAU ANZOÁtegUI, 2004, pp. 273274.

85 Como ya señalamos, esta figura había sido intensamente contestada por el Cabildo porteño en 1747 cuando Andonaegui pretendió instalarla en el gobierno urbano. En 1766, Bucareli confirmaba el nombramiento de comisarios menores, cada cuatro cuadras para que: "vigilen sobre el cumplimiento de las disposiciones que se han tomado para el aseo de la ciudad", TAU AnzoÁteguI, 2004, pp. 271-272. No obstante, la difícil relación que el Gobernador mantuvo con el Cabildo porteño y las tareas relativas a la expulsión de los Jesuitas que lo tuvieron fuera de la ciudad por largos períodos impidieron que el cargo de afianzara.

86 Bandos..., AGN, Sala IX, Gobierno, 8-10-3, fs. 169-172. La instalación de alcaldes de barrio fue una política generalizada tanto en España como en América. En 1769 se publicó en Lima el reglamento de policía por el cual se establecían las funciones de los mismos, vigilar el orden, velar por el mantenimiento de la infraestructura urbana (alcantarillado, acequias, iluminación, empedrado, basuras), evitar interrupciones; tanto del tránsito como del flujo hidráulico y dirimir conflictos entre vecinos. A estas obligaciones se sumó en 1770 el control y mantenimiento de un "libro de matrícula" por el cual cada Alcalde debía anotar a los habitantes de su jurisdicción (sexo, calidad, estado, oficio y nombre) y registrar sus movimientos mensualmente. De este modo, todo habitante tendría asignado un domicilio con un cuartel, un barrio, una calle y un número específico. Lo que no solo se vinculaba a las necesidades policiales sino también al manejo del sistema fiscal. Se trataba de ubicar a los habitantes en sus domicilios, para identificar mejor a los elementos móviles. Ver Amores Carredano, 2004; Perez Cantó, 1985, entre otros. 
los comisionados nombrados sepan las obligaciones a su cargo y consten a todos sus facultades y la sujeción y obediencia que les deben tener" ${ }^{\prime 7}$.

En principio quedaba a su cargo el cumplimiento de los bandos, tanto los ya publicados como aquellos a publicar referentes a: horarios de cierre de tahonas y canchas, pesas, medidas y calidad de las mercaderías en las tiendas y pulperías -sin perjuicio en las prerrogativas del Regidor fiel ejecutor-, el cuidado en torno a los "tratos ilícitos" y las cuestiones relativas al orden en las construcciones urbanas, temas como el tratamiento de las calles -que resulten parejas sin pozos ni pantanos-, la construcción de casas y el cierre de calzadas por parte de los vecinos, el aseo de las calles, el arreglo del tránsito y la construcción de los solares vacios.

En las instrucciones para los comisarios de barrio publicadas por Vertiz en forma de bando de buen gobierno, -lo que estaría connotando la intención de parte del Gobernador de que las mismas fueran conocidas por toda la población- es notable el esfuerzo por sistematizar el conocimiento de todos los estantes y habitantes de la ciudad, sus ocupaciones y su localización en el espacio. En primer lugar se encargó a cada uno de los comisarios la realización de un matricula a todos los "vecinos y residentes" en el barrio que le correspondiera con expresión individual de:

Nombres, estado, empleo u oficio que tengan, número de hijos, esclavos y sirvientes, de ambos sexos con sus clases y estados y ejercicios verificada esta diligencia ninguno de los matriculados podrá mudar de casa ni ausentarse a otro destino sin el previo aviso al comisionado ${ }^{88}$.

A los dueños de casas que alquilaban cuartos en sus propiedades se les ordenaba pasar por escrito la información de todas las personas que entrasen o saliesen de sus casas, exponiendo además "el motivo porque se ausentan, a donde y por donde vienen" 89 . Se ordenaba a los comisarios tener noticia detallada de los "vagos y malentretenidos" correspondientes a sus distrito para "aplicarlos donde convenga". Por último se ordenaba que: "Ningún pobre de ambos sexos mendicante por las calles podrá pedir limosna sin el correspondiente pasaporte o licencia del comisionado de su distrito" $"$.

A partir de la división y racionalización del espacio controlado por funcionarios especiales, los planteos borbónicos tempranos pretendieron favorecer el control social, la recolección de los impuestos y el desarrollo económico produciéndose a su vez una cierta reorientación desde el gobierno del ocio y de la recreación que evitara el desarrollo de conflictos sociales ${ }^{91}$. Por eso también disminuyó la reiteración de las

87 Bandos..., AGN, Sala IX, Gobierno, 8-10-3, f. 169. Uno de los argumentos esgrimidos en 1747 por parte de los capitulares para cuestionar y finalmente eliminar la figura de los comisarios tenía que ver con la falta de precisión en torno a los deberes y las prerrogativas que les correspondían.

88 Ibídem, f. 170.

89 "Las matriculas de vecinos, tiendas, pulperías, posadas o figones, harán con una hoja para cada casa, dejando todo el ámbito posible para anotar en ella las mudanzas o entradas de entre año", Ibídem, f. 171.

90 Ibídem, f. 171.

91 Ver Walker, 2008; Pérez Cantó, 1985; O’Phelan, 2005. Nuevamente respecto a los bailes de máscaras, Martín de Altolaguirre, como oficial de la Real Hacienda declaraba que: "le parece que esta diversión no solo es la más honesta y menos costosa para el pueblo sino que por el genio de sus habitantes, inclinados generalmente a los bailes halla ser lo más apropósito para que teniéndolos divertidos consiguientemente estén 
prohibiciones reseñadas y se las reemplazó por la mediación de un funcionario dedicado exclusivamente al control de la población en un espacio más acotado. La instalación de alcaldes de barrio tanto en España como en América fue una respuesta a las "nuevas necesidades urbanas" que emergieron durante el siglo XVIII ${ }^{92}$. Sin embargo, los testimonios de la época nos permiten dudar del éxito de estas políticas a la hora de limitar las situaciones de peligrosidad en las calles. De acuerdo a un observador de la época, hacia 1778 en Buenos Aires, "las muertes son casi continuas y todas de cuchilladas" ${ }^{93}$. No obstante consideramos que el propósito central de estas políticas, radicaba más bien en la conformación de un aparato gubernamental que funcionara como malla de contención y desde el cual se pudiese progresivamente verificar una presencia cada vez mayor de las autoridades y las directrices metropolitanas en el entramado urbano.

En este sentido retomamos las reflexiones de Antonio Hespanha, quien advierte que:

La división política del espacio es también un instrumento de poder. Es un `aparato político' que tanto sirve para organizar y estabilizar el poder de determinados grupos sociales como para desvalijar políticamente a otros ${ }^{94}$.

No obstante, el compromiso efectivo de la Corona borbónica con dichas políticas chocó con notables resistencias en el plano local, ${ }^{95}$ un breve repaso a los nombres de los nuevos comisarios de barrio nos muestra la persistencia en el gobierno de las mismas familias que dominaban el Cabildo y el funcionamiento de la justicia y del control social al menos desde la década de 1740, Fernando Caviedes, Juan de Lezica, Diego de Mantilla y los Ríos, Marcos Riglos, por citar algunos ${ }^{96}$.

Por otra parte, las trabas puestas a los desplazamientos de la población resultaban efectivas en las pequeñas ciudades, pero las mismas desaparecen con el avance de la urbanización. Tal como señala Johnson, la experiencia plebeya estuvo enmarcada por la dinámica del cambio demográfico por lo que la población urbana se encontraba

menos expuestos a inquietudes y desordenes. Información sobre..., 1773. AGN, Sala IX, Hacienda, legajo 6, expediente $105,32-8-5$, f. 11 .

92 Como parte de la misma política de control en 1782 se estableció el sistema de intendencias, en tanto órgano de gobierno con una mayor capacidad ejecutiva y fiscal, que los Gobernadores y cuyas funciones se delimitaron a territorios más pequeños, política que gozó de un éxito variable. Al respecto ver: PIETSCHMANN, 1996.

93 Pereira Fernández De Mesquita, 1980 [1778], p. 40.

94 Hespanha, 1993, pp. 88-89.

95 Como explica Pietschmann, 1996, el funcionamiento del aparato político y jurídico americanos suavizaban las políticas centralistas. La vigencia de las apelaciones, del derecho casuístico, y las postergaciones en la aplicación de las leyes reales, son una muestra de dicho fenómeno.

96 Por ejemplo, Caviedes compró el cargo de regidor en 1767 y ese mismo año, en su rol de comerciante al por mayor de la ciudad, contribuyó con cincuenta pesos para la presentación de Manuel Basavilbaso ante el Rey respecto a la libre internación de productos al Perú. AGN, 1927, pp. 549-553. Lezica fue Capitán de la milicia local y miembro del Cabildo, al tiempo que hizo carrera como gran comerciante aliado a la familia Basavilbaso. Sus hijos se incorporaron por casamiento a las familias Riglos y San Martín, Socolow, 1991, p. 134. Se desempeñó como regidor en el Cabildo entre 1751y1753, mientras que en 1754 y 1766 ocupó el oficio de alcalde de primer voto y en 1767 también colaboró en la representación iniciada por Manuel Basavilbaso. AGN, 1926 y 1927. 
en continua transformación dados los movimientos migratorios ${ }^{97}$. El efectivo cumplimiento de las disposiciones gubernamentales entrañaba contradicciones de fondo respecto a las situaciones que el mismo desarrollo urbano imponía, se ordenaba el cese de los juegos al mismo tiempo que se abrían establecimientos con ese fin, se planteaba la expulsión de los extranjeros a riesgo de perder a los oficiales mecánicos calificados, se reclamaba en torno a la multitud de pasantes cuando también se ordenaba que permanecieran en la plaza a aquellos que se allegaban a cubrir con sus productos el abasto urbano, ciertos sectores condenaban el comercio callejero, pero el mismo se imponía tanto en función de la demanda generada por el despegue económico de la población, como por las mismas necesidades financieras de las instituciones de gobierno urbano, por dar algunos ejemplos.

A lo largo de estas páginas pudimos observar de qué modo se vincularon, las transformaciones sociales -tanto en lo referido al aumento demográfico, pero también respecto al impacto que el aumento de la competencia por las oportunidades comerciales tuvo en el perfil de la sociedad porteña- con los modos a los que los encargados del gobierno urbano apelaron para limitar aquello que consideraban perjudicial y reorientar así el ocio hacia actividades más productivas. En este sentido señalamos dos etapas, la primera signada por el intento por lograr unos registros de población cada vez más sistemáticos y la emisión reiterada de determinadas prohibiciones. Ese cúmulo de ordenanzas refleja la búsqueda por una reorientación de las conductas de la población de parte de los encargados del gobierno. No obstante gobernadores como Andonaegui notaron la necesidad de contar con dispositivos más específicos para el cumplimiento de lo mandado, los juegos de poder locales bloquearon sus tentativas. La presencia de Vertiz en Buenos Aires perfiló nuevas formas de centralización respecto al rubro de policía en la ciudad, ahora mediatizado por funcionarios intermedios y el Gobernador reemplazó con ellos la costumbre de sus antecesores por reiterar las ordenanzas que hacían a la vida cotidiana. Quedaba instalada formalmente la institución de los comisarios de barrio, aunque en la práctica el incumplimiento a las normas permaneciese.

El ámbito urbano es por definición un espacio de contactos entre grupos sociales diversos, el crecimiento demográfico y espacial que se produjo en el siglo XVIII en Buenos Aires -y en toda Hispanoamérica- implicó el surgimiento de zonas de anonimato que para determinados sectores sociales representaban ámbitos de mayor libertad en los que los vínculos personales y la organización estamental se diluían junto con las calles de la traza en senderos y caminos. En este sentido cabe señalar que el proyecto social borbónico temprano, requería de un espacio urbano cada vez más ordenado, regular y simétrico que colaborase en las tareas de algún modo "civilizatorias" que ideológicamente se estaban proponiendo, calles limpias, parejas, "desembarazadas" y edificios cuya presencia señalase el poder Real en el entramado urbano. No obstante, las condiciones materiales de las ciudades hispanoamericanas en general y de Buenos Aires en particular, así como las prácticas de una población que crecía junto con el espacio construido y las costumbres políticas locales, no se condijeron necesariamente con dichos objetivos.

97 Johnson, 2011, p. 72. 


\section{REFERENCIAS BIBLIOGRÁFICAS}

Archivo General de la Nación Argentina (agn)

ACUERDos

1930 ---- del Extinguido Cabildo de Buenos Aires. AECBA, Serie II, Tomo VIII, Libro XIV y XXV (1739-1744). Buenos Aires. Municipalidad de la ciudad de Buenos Aires.

1931 ---- del Extinguido Cabildo de Buenos Aires. AECBA, Serie II, Tomo IX, Libro XXV, XXVI, XXVII (1745-1750). Buenos Aires. Municipalidad de la ciudad de Buenos Aires.

1926 ---- del Extinguido Cabildo de Buenos Aires. AECBA, Serie III, Tomo I, Libro XXVII, XXVIII, XXIX y XXX (1751-1755). Buenos Aires. Municipalidad de la ciudad de Buenos Aires.

1927 ---- del Extinguido Cabildo de Buenos Aires. AECBA, Serie III, Tomo III, Libros XXXIII - XXXIV - XXXV (1762-1768). Buenos Aires. Municipalidad de la ciudad de Buenos Aires.

1928 ---- del Extinguido Cabildo de Buenos Aires. AECBA, Serie III, Tomo V, Libros XXXVI, XXXVII, XXXVIII, XXXIX, XL (1774-1776). Buenos Aires. Municipalidad de la ciudad de Buenos Aires.

Amores Carredano, Juan Bosco

2004 "Ordenanzas de gobierno local en la isla de Cuba (1765-1786)". Revista Complutense de Historia de América. Madrid, n 30, pp. 95-109.

BARRENECHe, Osvaldo

2001 Dentro de la ley, todo. La justicia criminal en Buenos Aires en la etapa formativa del sistema penal moderno de la Argentina. La Plata. Al Margen.

Buschiazzo, Mario

1941 Buenos Aires y Córdoba en 1729 según cartas de los padres C. Cattaneo y C. Gervasoni, SJ. Buenos Aires. CEPA.

Chiaramonte, José Carlos

2005 "La etapa ilustrada 1750-1806". En Assadourian - Beato - Chiaramonte, Historia argentina II. De la conquista a la independencia. Buenos Aires. Paidós, pp. 281-369.

Díaz, Marisa

1998 "Las migraciones internas a la ciudad de Buenos Aires, 1744-1810". Boletín del Instituto de Historia Argentina y Americana "Dr. Emilio Ravignani". Buenos Aires, tercera serie, $\mathrm{n}^{\circ}$ 16-17, pp. 7-31.

ElLiotT, John Huxtable

2006 Empires of the Atlantic World: Britain and Spain in America, 1492-1830. New Haven. Yale University Press.

FACULTAD DE FILOSOFÍA Y LETRAS

1919 Documentos para la historia argentina. Tomo X, padrones de la ciudad y campaña de Buenos Aires, 1726-1810. Buenos Aires. Peuser. 
Gelman, Jorge

1989 "Sobre el carácter del comercio colonial y los patrones de inversión de un gran comerciante en el Río de la Plata del siglo XVIII". Boletín del Instituto de Historia Argentina y Americana "Dr. E. Ravignani". Buenos Aires, tercera serie, ${ }^{\circ} 1$, pp. 51-69.

Herzog, Tamar

2006 Vecinos y extranjeros. Hacerse español en la Edad Moderna. Madrid. Alianza.

Hespanha, Antonio M.

1993 La gracia del derecho. Economía de la cultura en la Edad Moderna. Madrid. Centro de Estudios Constitucionales.

Johnson, Lyman - Socolow, Susan

1980 "Población y espacio en el Buenos Aires del siglo XVIII". Desarrollo económico. Revista de Ciencias Sociales. Buenos Aires, vol. 20, n 79, pp. 329349.

JoHNSON, Lyman

2011 Workshop of revolution: plebeian Buenos Aires and the Atlantic world, 17761810. Durham. Duke University Press.

1992 "La historia de los precios de Buenos Aires durante el período virreinal". En Johnson - Tandeter (comps.), Economías coloniales. Precios y salarios en América Latina, siglo XVIII. Buenos Aires. Fondo de Cultura Económica, pp. 153-190.

1979 "Estimaciones de la población de Buenos Aires en 1744, 1778 y 1840". Desarrollo Económico. Buenos Aires, vol. 19, nº 73, pp. 107-119.

KONETZKe, Richard

1987 La época colonial. Madrid. Siglo XXI.

LEMPÉRIÈRE, Annick

2000 "La recepción negativa de una gran idea: el absolutismo en Nueva España en la segunda mitad del siglo XVIII". En QuiJada - Bustamante, Elites intelectuales y modelos colectivos. Mundo ibérico (siglos XVI-XIX). Madrid. CSIC, pp. 199-218.

LoRANDI, Ana María

2008 Poder central, poder local. Funcionarios borbónicos en el Tucumán colonial. Un estudio de antropología política. Buenos Aires. Prometeo.

Lugar, Catherine

1992 "Comerciantes". En Hoberman - Socolow (comps.), Ciudades y sociedad en Latinoamérica colonial. Buenos Aires. Fondo de Cultura Económica, pp. 67104.

Moreno, José Luis

2006 "Españoles y criollos". En Romero - Romero (dirs.), Buenos Aires. Historia de cuatro siglos. Tomo I. Buenos Aires. Altamira, pp. 79-90. 
Mörner, Magnus

1992 Aventureros y proletarios. Los emigrantes en Hispanoamérica. Madrid. Mapfre.

Moutoukias, Zacarías

2000 "Gobierno y sociedad en el Tucumán y el Río de la Plata, 1550-1800". En TANDeter (dir.), Nueva historia Argentina. La sociedad colonial, Tomo II. Buenos Aires. Sudamericana, pp. 335-411.

Navarro Viola, Miguel - Gregorio Quesada, Vicente (dirs.)

1863 La revista de Buenos Aires. Historia americana, literatura y derecho. Periódico destinado a la República Argentina, la Oriental del Uruguay y del Paraguay, Tomo II. Biblioteca Americana. Buenos Aires. En http://books. google.com.ar/books?id=XPgvAAAAYAAJ\&dq=\%225+de + octubre + de +17 $16 \% 22+\% 22$ muy + noble $+y+$ muy + leal $\% 22 \& h l=e s \&$ source $=$ gbs_navlinks_s

O'Phelan, Scarlett

2005 "Orden y control en el siglo XVIII. La política borbónica frente a la corrupcion fiscal, comercial y administrativa". En Portocarrero (ed.), El pacto infame. Estudios sobre la corrupción en el Perú. Lima. Red para el Desarrollo de las Ciencias Sociales en el Perú, pp. 13-33.

Pereira Fernández de mesquita, Pedro

1980 [1778] Relación de la conquista de Colonia por D. Pedro de Cevallos y descripción de la ciudad de Buenos Aires. Buenos Aires. Academia Nacional de la Historia.

Pérez Cantó, M. Pilar

1985 Lima en el siglo XVIII. Estudio socioeconómico. Madrid. UAM.

Pietschmann, Horst

1996 Las reformas borbónicas y el sistema de intendencias en Nueva España. México. Fondo de Cultura Económica.

QuARLERI, Lía

2009 Rebelión y guerra en las fronteras del Plata: guaranies, jesuitas e imperios coloniales. Buenos Aires. Fondo de Cultura Económica.

RaVignani, Emilio

1920 "Crecimiento de la población de Buenos Aires y su campaña (1726-1810)". En Facultad de Filosofía y Letras, UBA, Documentos para la historia argentina, Tomo X. Padrones de la ciudad y su campaña 1726-1810. Buenos Aires. Peuser, pp. 2-10.

ReITANo, Emir

2004 Los portugueses del Buenos Aires tardocolonial. Tesis de doctorado. La Plata. Universidad Nacional de La Plata.

Rípodas Ardanaz, Daisy

2002 Viajeros al Río de la Plata (1701-1725). Buenos Aires. Academia Nacional de la Historia. 
SANTAMARÍA, Daniel

2006 "La población: estancamiento y expansión, 1580-1855”. En ROMERO - ROMEro (dirs.), Buenos Aires. Historia de cuatro siglos. Buenos Aires. Altamira, pp. 211-223.

Socolow, Susan

1991 Los mercaderes del Buenos Aires virreinal: familia y comercio. Buenos Aires. Ediciones De la Flor.

STUDER, Elena

1958 La trata de negros en el Río de la Plata durante el siglo XVIII. Buenos Aires. Universidad de Buenos Aires.

Tau Anzoátegui, Victor

2004 Los bandos de buen gobierno del Río de la Plata, Tucumán y Cuyo (época hispánica). Buenos Aires. Instituto de Historia del Derecho.

1992 "Una defensa de los extranjeros en el Buenos Aires de 1743". En TAU ANzoÁtegui, La ley americana en América hispana. Del descubrimiento a la emancipación. Buenos Aires. Academia Nacional de la Historia, pp. 277-292.

TAu AnZoÁtegui, Víctor - Martiré, Eduardo

2006 Manual de historia de las instituciones argentinas. Buenos Aires. Librería Histórica.

Valarezo Dueñas, Aurelio

2013 "Los orígenes jurídicos del sistema político imperial español y su influencia en las Américas". Procesos. Revista Ecuatoriana de Historia. Quito, n 37, pp. 5-34.

WALKER, Charles

2008 Shaky colonialism. The 1746 earthquake in Lima, Peru, and its long aftermath. Londres. Duke University Press.

Zabala, Rómulo - De Gandía, Enrique

1937 Historia de la ciudad de Buenos Aires II (1719-1800). Buenos Aires. Municipalidad de la ciudad de Buenos Aires. 